Nutr. Metabol. 1975;19:I-V

\title{
Contents, Vol. 19, 1975
}

\section{Nutrition and Metabolism}

Journal of Nutrition, Metabolic Diseases and Dietetics

N. Zöllner, Munich

E.M. Widdowson, Cambridge G. Wolfram, Munich

Main Editor Associate Editors

Editorial Board

W. Auerswald, Vienna

K.J. Carpenter,

Cambridge

H.-D. Cremer, Giessen

I. W. T. Dickerson,

Guildford

F. Falkner,

Yellow Springs, Ohio

F. Fidanza, Perugia

R. Gitzelman, Zurich G. Hartmann, Chur C. den Hartog, Rijswijk K. Hellström, Stockholm S. Heyden, Durham, N.C. F.A. Hommes, Groningen B. Jacotot, Créteil H. Kapp, Basel E. Kodicek, Cambridge

/. Macdonald, London H.K. Mangold, Münster K.R. Norum, Oslo G. Schlierf, Heidelberg J.C. Somogyi, Zurich /. Trémolières, Paris A.J. Vergroesen, Vlaardinge n-D uiven A. Wretlind, Stockholm

S. Karger $\cdot$ Basel $\cdot$ München $\cdot$ Paris $\cdot$ London $\cdot$ New York $\cdot$ Sydney

S. Karger · Basel · München · Paris · London · New York · Sydney Arnold-Böcklin-Strasse 25, $\mathrm{CH}-4011$ Basel (Switzerland)

All rights, including that of translation into other languages, reserved. Photomechanic reproduction (photocopy, microcopy) of this volume or parts thereof without special permission of the publishers is prohibited.

(C) Copyright 1975 by S. Karger AG, Verlag fur Medizin und Naturwissenschaften, Basel Printed in Switzerland by Thür AG Offsetdruck, Pratteln

Index

No. 1-2

Tuovinen, C.G.R. and Bender, A.E. (London): Effect of Dietary Sucrose and Fructose on the Metabolism and Lipid Fractions in Liver in the Rat 1

Pointillart, A. et Meslin, J.C. (Jouy-en-Josas): Effet à moyen terme de la teneur en magnesium d'un regime riche en huile de colza sur Гapparition des lesions du myocarde chez le rat (Effect of Dietary Magnesium Levels on Cardiac Lesions in Rats Fed a Diet Rich in Rapeseed Oil) 10 Lai, H. and Agarwal, K.N. (Varanasi): Influence of Experimental Dietary Conditions 
on Hepatic Enzymes of Glutamic Acid Metabolism in Rats 20

Demarne, Y.; Toure, M.; Flanzy, J. et Lecourtier, M.J. (Jouy-en-Josas): Influence du degré d'insaturation des lipides alimentaires sur la croissance et la lipogénèse chez le rat (Effect of Unsaturated Dietary Fats on Growth and Lipogenesis in the Rat) ... 28

Johnson, O. and Hernell, O. (Umeå): Effect of Ethanol on the Activity of Lipoprotein Lipase in Adipose Tissue of Male and Female Rats 41

Szepesi, B.; Vegors, R.; Michaelis, O.E., IV, and DeMouy, J.M. (Beltsville, Md.): LongTerm Effects of Starvation-Refeeding in the Rat 45

Cetorelli, L ·; Galante, A., and Pennetti, V. (Rome): Patterns of Urinary Iodine Excre tion in a Newly Identified Goitrous Area of Central Sicily 55

Sugano, M.; Imaizumi, K., and Karno, F. (Fukuoka): Nutritional Regulation of Lipid Metabolism in Rats. VII. Effect of Overnight Fasting on Liver Lipids of Rats Fed Different Levels of Essential Fatty Acids 65

Bourne, A.R., Richardson, D.P.; Bruckdorfer, K.R., and Yudkin, J. (London/Greenford, Middx.): Some Effects of Different Dietary Carbohydrates on Pregnancy and Lactation in Rats 73

Mahboob, S. (Pittsburgh, Pa.): Effect of Pantothenic Acid Deficiency on Microsomal Lipids of Rat Liver 91

Sprandel, U.; Heuckenkamp, P.-U., and Zöllner, N. (Munich): Utilization of Intra venous Maltose 96

Bach, A.; Phan, T., and Metais, P. (Strasbourg): Influence of a Long or Medium Chain Triglyceride Diet on Intermediary Hepatic Metabolism of the Rat 103

Book Reviews · Buchbesprechungen · Livres nouveaux 111

Index

IV

No. 3-4

Rocquelin, G.; Juanéda, P.; Péleran, J.C. et Astorg, P.O. (Dijon): Effets compares, à très court terme, des acides n-9, frø«s-docosénoïque (brassidique) et n-9, cis-docosénoïque (érucique) sur les lipides cardiaques du rat sevré (Short-Term Comparative Study of Effects of n-9 rrø «sDocosenoic [Brassidic] Acid and n-9, $\mathrm{c}^{1 / 8} \mathrm{-D}$-Docosenoic [Erucic] Acid on the Cardiac Lipids of Wealing Rats) 113

Larking, P. and Nye, E.R. (Dunedin): Increased Levels of Esterified Arachidonic Acid in Plasma by Feeding $\gamma$-Linolenic Acid 127

Griglío, S. and Malewiak, M.I. (Paris): Hepatic Triglyceride Storage and Ketonemia in Rats Fed High Fat Diets 131

El Nockrashy, A.S.; Kiewitt, M.; Mangold, H.K., and Mukheńee, K.D. (Münster):

Nutritive Value of Rapeseed Meals and Rapeseed Protein Isolates 145

Gontzea, I.; Gorcea, V., and Popescu, F. (Bucharest): Biochemical Assessment of

Thiamin in Patients with Neurosis 153

Ghavami Nejad A. and Mohagheghpour, N. (Teheran): Cellular Immunity in Mal nourished Mice 158

Tuovinen, C.G.R. and Bender, A.E. (London): Some Metabolic Effects of Prolonged

Feeding of Starch, Sucrose, Fructose and Carbohydrate-Free Diet in the Rat ... 161

Eklund, A. (Uppsala): Outcome of Pregnancy from Day 0 to 19 and Serum Tocopherol

Levels in Mother Rats Fed on a Rapeseed Protein Concentrate Essentially Free

from Glucosinolates 173 
Drevon, C.A. and Norum, K.R. (Oslo): Effect of Lipid Emulsions on the Plasma Lecithin:Cholesterol Acyltransfer in Guinea Pigs 180

Hovland, W.N.; Thomas, G.W., and Kline, E.S. (Richmond, Va.): A Model System for Direct in vivo Measurement of Absorbed Nutrients in Portal Venous Blood. Ap plicability to Alcohol Studies 192

Hartley, T.F. and Lee, H.A. (Portsmouth/Southampton): Investigations into the Optimum Nitrogen and Caloric Requirements and Comparative Nutritive Value of Three Intravenous Amino Acid Solutions in the Post-Operative Period 201 Groener, J.E.M. and Macdonald, I. (London): Lipid Response to Female Gonadal Hormones of Female Rats Fed a High Glucose or a High Fructose Diet 212 Varia 223

Erratum 224

No. 5-6

Bruckdorfer, K.R. and Yudkin, J. (London): A Comparison of Dietary Starch and Dietary Sucrose in the Pig 225

Brodan, V.; Brodanová, M.; Kuhn, E.; Filip, J., and Pechar, J. (Prague): Ammonia and Uric Acid Formation after Rapid Intravenous Fructose Administration to Healthy Subjects and Patients with Compensated Cirrhosis of the Liver 233 Giesing, M.; Neumann, G.; Egge, H, and Zilliken, F. (Bonn): Lipid Metabolism of Developing Central Nervous Tissues in Organotypic Cultures. I. Lipid Distribution and Fatty Acid Profiles of the Medium for Rat Brain Cortex in vitro 242 Giesing, M. and Zilliken, F. (Bonn): Lipid Metabolism of Developing Central Nervous Tissues in Organotypic Cultures. II. A Comparative Study of Medium and Tissue Fatty Acids in Developing Rat Cerebral Cortex and Cerebellum 251 Index $\mathrm{V}$

Hommes, F.A.; Mastebroek-Helder, D.J., and Molenaar, I. (Groningen): The Effect of Vitamin E Deficiency on Permeability of Mitochondria for Phosphate 263 Schnegg, A. und Kirchgessner, M. (Freising-Weihenstephan): Veränderungen des Hämoglobingehaltes, der Erythrozytenzahl und des Hämatokrits bei Nickelmangel (Changes in the Hemoglobin Content, Erythrocyte Count and Hematocrit in Nickel Deficiency) 268

Kramer, J.K.G.; Friend, D.W., and Hulan, H.W. (Ottawa, Ont.): Lipid Changes in Tissues of Young Boars Fed Rapeseed Oil or Corn Oil 279

Wisc., A. (London): Adipocyte Number and Size in Hypothalamic Obesity Induced in Weanling Mice by Gold Thioglucose and Bipiperidyl Mustard 291

Srinivas, L. and Rama Rao, P.B. (Mysore): Studies on Liver Sulphurylase Activity in Rats: Vitamin-A-Deficient and Low-Protein Diets 299

Nouvelot, A.; Dewailly, P.; Fruchart, J.C; Jaillard, J. et Sezille, G. (Lille): Etude métabolique de trois emulsions lipidiques utilisées dans $\Gamma$ alimentation parentérale. I. Exploration in vivo chez le miniporc

(Metabolism Study of Three Fat Emulsions for Intravenous Nutrition. I. Effects in Minipigs) 307

Dewailly, P.; Trupin, N.; Nouvelot, A.; Fruchart, J.C; Jaillard, J. et Sezille, G. (Lille): Etude métabolique de trois emulsions lipidiques utilisées dans $\Gamma$ alimentation parentérale. II. Etude par perfusion de foie de rat isolé 
(Metabolism Study of Three Fat Emulsions for Intravenous Nutrition. II. Study by Isolated Rat Liver Preparation) 318

Author Index 327

Subject Index

328 